
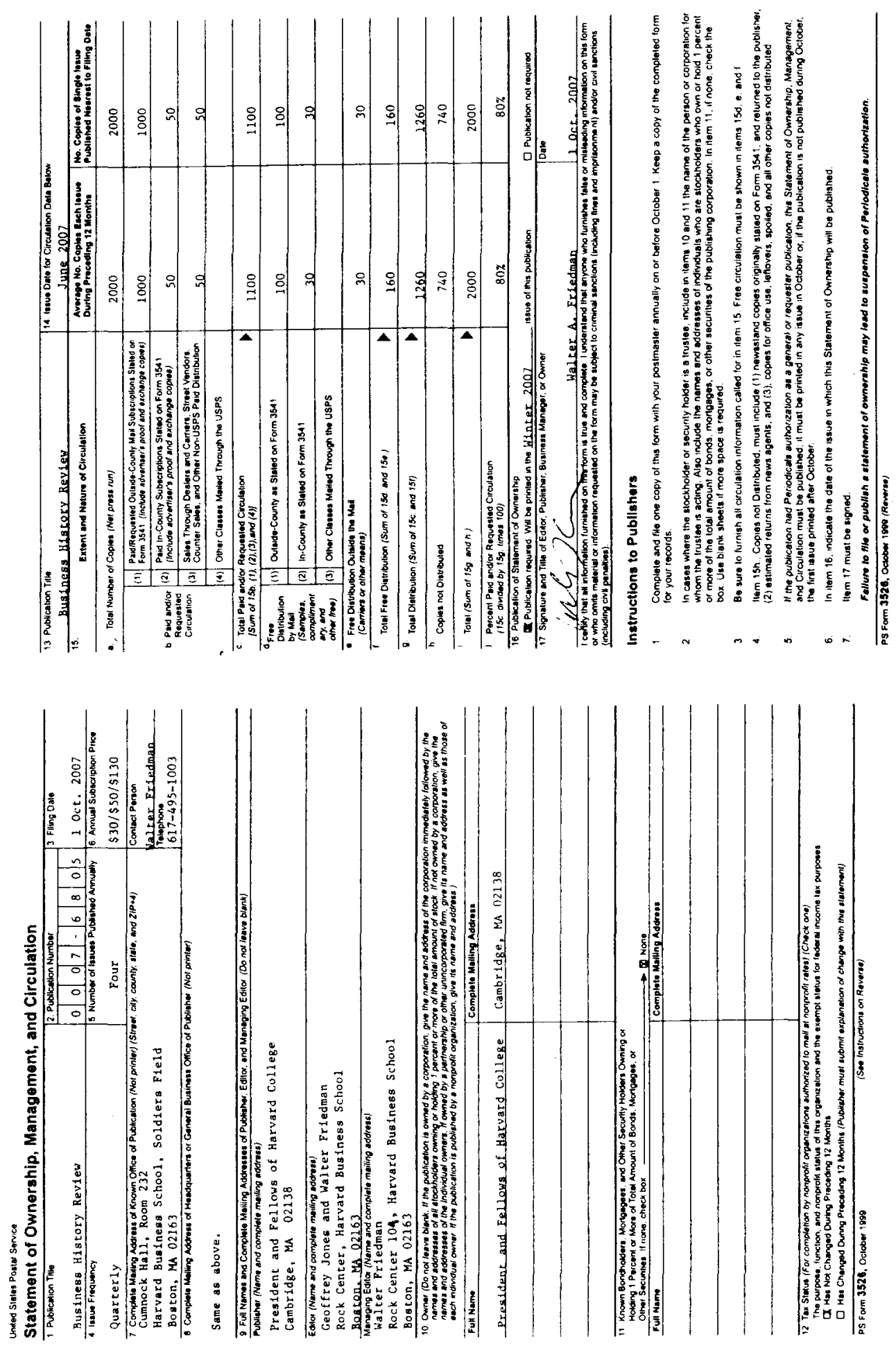

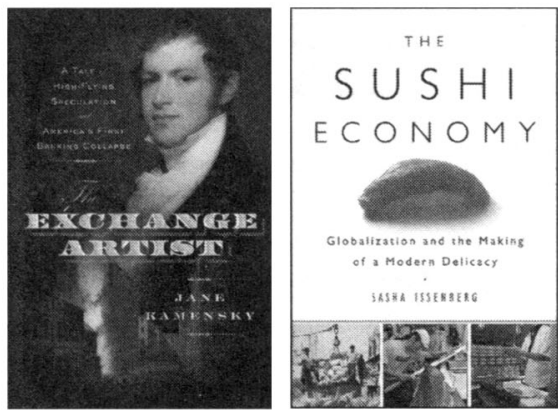

Jane Kamensky

\section{The Exchange Artist}

A Story of Paper, Bricks, and Ash in Early National America

"A dazzling, disturbing account of rising and falling in early America, a tale of towering ambition and catastrophic collapse."

-Jill Lepore, Harvard University.

Viking $\quad 448 \mathrm{pp} . \quad 978-0-670-01841-3 \quad \$ 29.95$

Available February 2008

\section{Sasha Issenberg}

\section{The Sushi Economy}

Globalization and the

Making of a Modern Delicacy

"A riveting and witty inquiry into the raw fish explosion. As a non-fiction stylist, he's first-rate. A must read!"

-Douglas Brinkley, Tulane University.

Gotham $352 \mathrm{pp} . \quad 978-1-59240-294-6 \quad \$ 26.00$

\section{Dana Thomas}

\section{Deluxe: How Luxury Lost Its Luster}

"Documents in entertaining and sometimes heart-wrenching detail how the luxury industry evolved from a proudly diverse array of family-owned houses into a \$157 billion-a-year mass market."

- Los Angeles Times.

Penguin Press 384 pp. 978-1-59420-129-5 \$27.95

\section{David S. Landes}

Dynasties: Fortunes and Misfortunes of the World's Great Family Businesses "Fascinating...an intriguing read."

-BusinessWeek.

Penguin $\quad 400$ pp. $\quad 978-0-14-311247-1 \quad \$ 16.00$
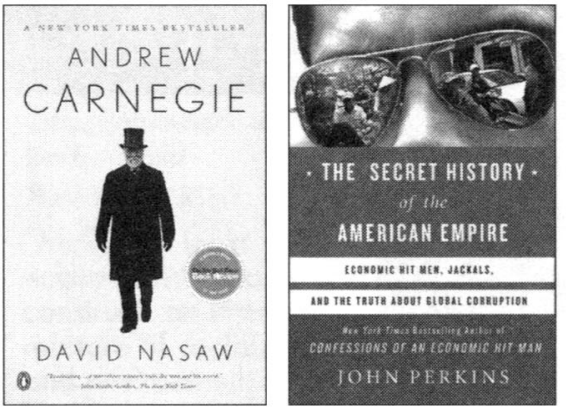

John Perkins

\section{The Secret History of the American Empire}

Economic Hit Men, Jackals, and the Truth about Global Corruption "An important, disturbing look beyond the headlines of why America is at war."

-Rocky Mountain News.

Dutton $\quad 384$ pp. $\quad 978-0-525-95015-8 \quad \$ 25.95$

\section{David Nasaw}

\section{Andrew Carnegie}

"A vivid history of nineteenth-century capitalism."-Fortune.

Penguin $\quad 896$ pp. $\quad 978-0-14-311244-0 \quad \$ 20.00$

\section{Tom Perkins}

\section{Valley Boy}

The Education of Tom Perkins

The revealing memoir from the venture capitalist and Silicon Valley pioneer whose resignation from the Hewlett-Packard board of directors broke one of the biggest scandals in the history of corporate America.

Gotham 304 pp. $\quad 978-1-59240-313-4 \quad \$ 27.50$

\section{Also of Interest:}

NEW IDEAS FROM DEAD ECONOMISTS: An Introduction to Modern Economic Thought Todd G. Buchholz Revised Edition

Foreword by Martin Feldstein

Plume $\quad 336$ pp. $\quad 978-0-452-28844-7 \quad \$ 16.00$

THINK INDIA: The Rise of the World's Next Superpower and What It Means for Every American Vinay Rai \& William L. Simon

Dutton 336 pp. 978-0-525-95020-2 \$25.95 


\section{New in paperback}

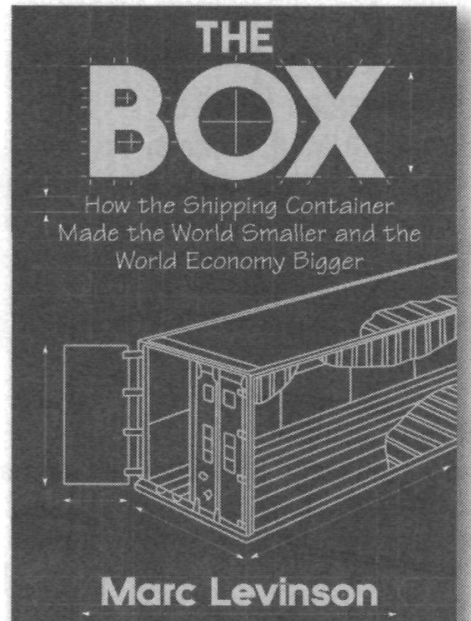

Short-listed for the 2006 Financial Times/Goldman Sachs Business Book of the Year

Winner of the 2007 Bronze Award in Financel Investment/Economics, Independent Publisher

Winner of the 2007 Anderson Medal, Society for Nautical Research

With a new preface by the author

\section{The Box}

How the Shipping Container Made the World Smaller and the World Economy Bigger

\section{Marc Levinson}

"[Levinson] makes a strong case that it was McLean's thinking that led to modern-day containerization. It altered the economics of shipping and with that the flow of world trade. Without the container, there would be no globalization."

\section{-Economist}

"[A] classic tale of trial and error, and of creative destruction."

-Virginia Postrel, New York Times

"By artfully weaving together the nuts and bolts of what happened at which port with the grand sweep of economic history, Levinson has produced a marvelous read for anyone who cares about how the interconnected world economy came to be." -Neil Irwin, Washington Post

"[A] fascinating exposition of the romance of the steel container. I'll never look at a truck in the same way again."

- Howard Davies, Times (London)

"[An] ingenious analysis."

- Stefan Stern, Financial Times

Paper $\$ 14.95$ 978-0-691-13640-0 Due February 


\section{New Books from YALE}

\section{Wall Street}

America's Dream Palace

STEVE FRASER

\section{"A brilliant and vivid} examination of how the Street came to inhabit and convulse America's collective psyche. No

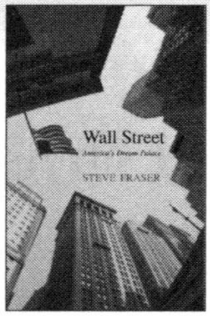
one has written about this essential American story with more subtlety, power, and insight." - Gary Gerstle Icons of America series 6 illus. \$22.00

\section{The Hamburger}

\section{A History}

\section{JOSH OZERSKY}

In this lively and entertaining history of the hamburger, Ozersky uncovers an array of facts and stories about the hamburger's evolution and chronicles how the burger has reflected-and even shaped-American business and culture. A Caravan Book: www.caravanbooks.org Icons of America series 15 illus $\$ 22.00$

\section{Innovation and the State}

Political Choice and Strategies for Growth in Israel, Taiwan, and Ireland

\section{DAN BREZNITZ}

"In this important book, Breznitz provides new insights into the very different strategies pursued by three very different countries-Israel, Taiwan and Irelandthat each used to post remarkable postWar growth records." - Robert E. Litan 11 illus. $\$ 45.00$

\section{Origins of American Health Insurance}

A History of Industrial Sickness Funds JOHN E. MURRAY

"A strikingly original reconsideration of Progressive-era industrial sickness fundstheir track record, their appeal for highmobility American workers, and their political implications." - Gavin Wright Yale Series in Economic and Financial History 22 illus. $\$ 40.00$
Auto Mania

Cars, Consumers, and the Environment

TOM MCCARTHY

"McCarthy looks at the environment broadly and constructs an interesting

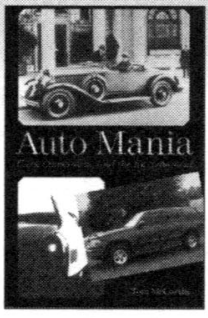
mixture of social, economic, political, and environmental history of the car not found elsewhere." - J. Brooks Flippen 52 illus. \$32.50

\section{Hotel}

An American History

\section{A. K. SANDOVAL-STRAUSZ}

"In this lucid and creative work, SandovalStrausz situates the rise of hotels within the history of the triumph of capitalism and of an increasingly mobile society. . . .

Fascinating." -Publishers Weekly

$58 \mathrm{~b} / \mathrm{w}+93$ color illus. $\$ 37.50$

\section{A Revolution in Commerce}

The Parisian Merchant Court and the Rise of Commercial Society in EighteenthCentury France

AMALIA D. KESSLER

"An erudite, original, and compelling treatment of one of the great problems of modern historiography: the relationship between capitalism and merchant practices, on the one hand, and late eighteenth-century political revolution, on the other." -John Fabian Witt

5 illus. $\$ 55.00$

New in paper

The American Dream vs. The Gospel of Wealth

The Fight for a Productive Middle-Class

Economy

NORTON GARFINKLE

\section{"This fascinating guided tour of}

America's past reminds us of the moral dimension of economic policy-which used to loom large, but which lately has been submerged." - Alan Blinder

The Future of American Democracy Series 3 illus. $\$ 16.00$ paperback 


\section{CAMBRIDGE}

\section{Understanding Multinationals: Then and Now}

Multinational Corporations and the New Global History

Edited by

Alfred D. Chandler, Jr.

Harvard University

\section{Bruce Mazlish}

Massachusetts Institute of Technology

"This book is a major contribution to our understanding of the origins and development of the multinational corporation.... This collection will be of great interest to scholars in economics, economic history, and business and organizations."

- David J. Teece, Mitsubishi Bank Professor of International Business and Finance, Haas School of Business, University of California, Berkeley

\section{Leviathans}

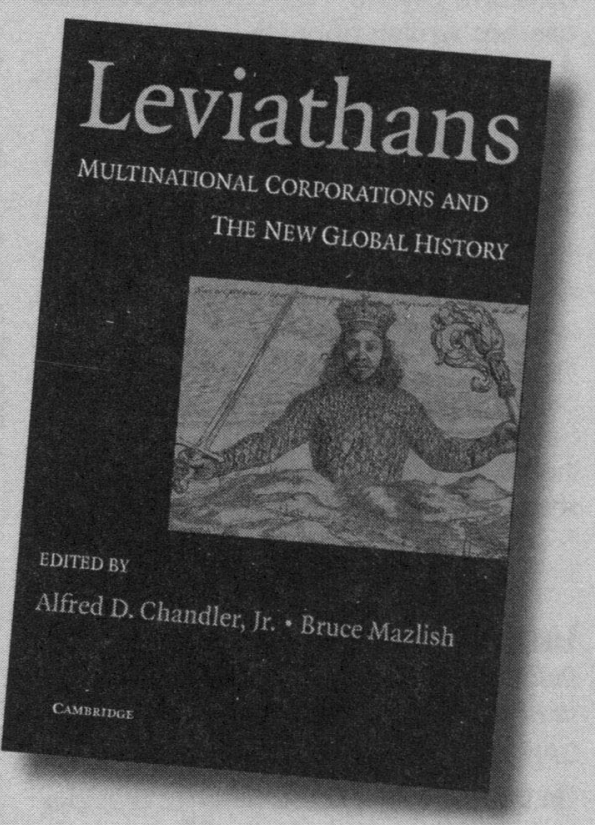

eviathans is a path-breaking effort to look at multinational corporations in the round, emphasizing especially their scope, history and development, cultural and social implications, and governance problems. Starting with a primer on MNCs, there are eight chapters devoted to a variety of aspects, including global elites. Written by experts on various elements of the MNCs, the book weaves a coherent and compelling picture of the way these "businesses" affect almost all areas of our existence in society and how they play a major role - political, cultural, and social - in the globalization that is reshaping so much of our lives.

\$69.00: Hardback: $978-0-521-84061-3: 264 \mathrm{pp}$.

\$24.99: Paperback: $978-0-521-54993-6$ 


\section{GUIDELINES FOR CONTRIBUTORS}

\section{GENERAL INFORMATION}

Manuscripts are considered for publication on the understanding that they are not concurrently under consideration elsewhere and that the material-in substance as well as formhas not been previously published.

Manuscripts should be submitted by e-mail to bhr@hbs.edu.

Authors should identify themselves only on a separate title page that provides name, mailing address, and telephone number. Authors must also remember not to identify themselves in the body of the manuscript; specifically, references to their own work in the text should be in the third person, and citations should be written without possessive pronouns-not "See my ...."

It will save considerable work for all parties in the event of acceptance if authors follow a few rules from the beginning:

- In general, use as few formatting commands as possible.

- Left justify text.

- Do not hyphenate words at the end of lines.

- ALL material-including extracted quotations and notes-must be double spaced.

- Notes should be numbered consecutively and citations should be placed as footnotes or endnotes formatted as indicated by The Chicago Manual of Style (2003).

- Each table and figure must be accompanied by a complete source.

Each article should be accompanied by an abstract of 75 to 100 words outlining the main point(s) of the paper and placing the article in context. Subheads should be used to divide the manuscript into three or four sections (or more, depending on length). The manuscript length, including footnotes, should not exceed 10,000 words.

We are always eager to publish illustrations, but authors should not include originals of illustrative materials at the time of submission; photocopies of such material may be included. Authors are responsible for obtaining all illustrative materials and permissions for reproduction, and for writing captions.

Authors of accepted manuscripts will receive two copies of the issue in which the article appears and twenty-five offprints.

\section{MANUSCRIPT PREPARATION}

We use the 15th edition of The Chicago Manual of Style (2003) and spell and hyphenate words according to the 11th edition of Merriam-Webster's Collegiate Dictionary.

The journal encourages authors to use gender-neutral prose in all cases where it is not anachronistic to do so; male nouns and pronouns should not be used to refer to people of both sexes. We use the day-month-year form for dates, as in 11 Feb. 1998, in the notes, but in the text, dates are written month-day-year, as in February 11, 1998. Double quotation marks should be used for direct quotation; single quotation marks are used for quoted material inside quotations.

\section{SAMPLE CITATION FORMS}

Book: Alfred D. Chandler Jr., The Visible Hand: The Managerial Revolution in American Business (Cambridge, Mass., 1977), 321-22.

Journal: Charles Cheape, "Not Politicians but Sound Businessmen: Norton Company and the Third Reich," Business History Review 62 (Autumn 1988): 444-66.

Note that we do not include the publisher in book citations. We do not use loc. cit., op. cit., or idem., but ibid. (not italicized) may be used. 


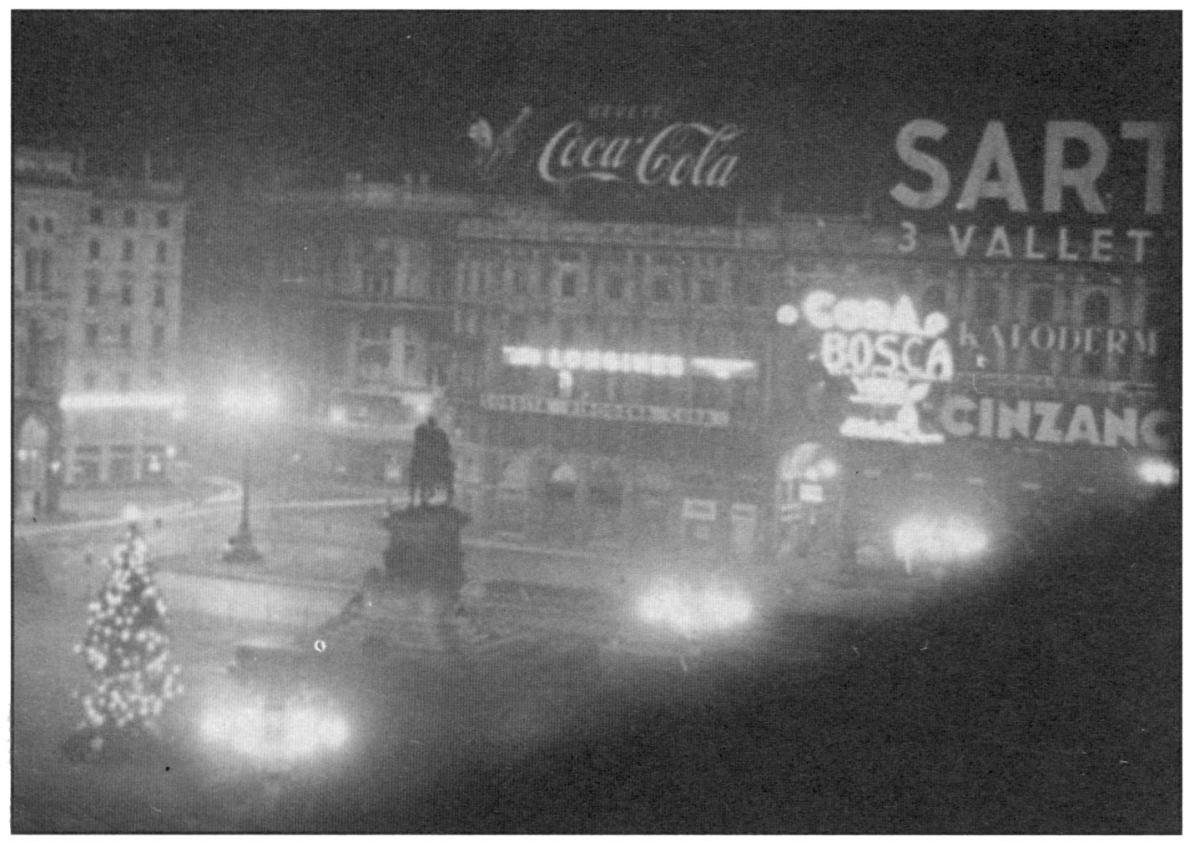

Piazza del Duomo, Milan, c. 1953-54

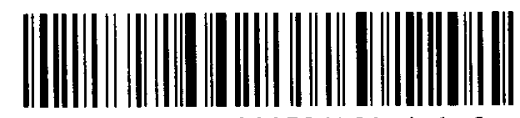

0007-6805 (200724) 81:4;1-6 